\title{
New bryozoan species from the Pleistocene of the Wanganui Basin, North Island, New Zealand
}

\author{
Emanuela DI MARTINO ${ }^{1, *}$, Paul D. TAYLOR ${ }^{2}$, Dennis P. GORDON ${ }^{3}$ \& Lee Hsiang LIOW ${ }^{4}$ \\ ${ }^{1,2}$ Department of Earth Sciences, Natural History Museum, \\ Cromwell Road, London SW7 5BD, United Kingdom. \\ ${ }^{3}$ National Institute of Water and Atmospheric Research (NIWA), Wellington, New Zealand. \\ ${ }^{4}$ Natural History Museum, University of Oslo, Oslo, Norway and Centre for Ecological and \\ Evolutionary Synthesis, Department of Biosciences, University of Oslo, Oslo, Norway. \\ *Corresponding author: e.di-martino@nhm.ac.uk \\ ${ }^{2}$ Email: p.taylor@nhm.ac.uk \\ ${ }^{3}$ Email: dennis.gordon@niwa.co.nz \\ ${ }^{4}$ Email: 1.h.liow@ibv.uio.no

\footnotetext{
${ }^{1}$ urn:1sid:zoobank.org:author:A7905C48-FF37-4D27-BCCE-F0560AF040A2

${ }^{2}$ urn:lsid:zoobank.org:author:7AFF2929-DF5B-46B2-94E6-B26B396CC2C8

${ }^{3}$ urn:Isid:zoobank.org:author:DD9C0F3A-8512-4AC8-B395-7687CE3FC565

${ }^{4}$ urn:1sid:zoobank.org:author:9A708FAA-486A-4918-AAC9-AF7795F3B675
}

\begin{abstract}
Three new fossil bryozoan species, a ctenostome and two cheilostomes, are described and figured from Pleistocene strata of the Wanganui Basin, New Zealand. Buskia waiinuensis sp. nov., a soft-body ctenostome preserved as a mould bioimmuration, is the first fossil record of the genus from New Zealand. Microporella rusti sp. nov., which is notable for the lack of ooecia in the large suite of colonies available, is one of the most common bryozoans in the Nukumaru Limestone and Nukumaru Brown Sand shellbeds, forming large encrusting sheet-like colonies, but is uncommon in younger beds. Rare, small-sized colonies of Parkermavella columnaris sp. nov. were found as fossil in two Quaternary beds, the Nukumaru Limestone and the Upper Kai-Iwi Shellbed, and also alive on rocks from the greater Cook Strait area.
\end{abstract}

Keywords. Pleistocene, Recent, Ctenostomata, Cheilostomata, bioimmuration.

Di Martino E., Taylor P.D., Gordon D.P. \& Liow L.H. 2017. New bryozoan species from the Pleistocene of the Wanganui Basin, North Island, New Zealand. European Journal of Taxonomy 345: 1-15. https://doi.org/10.5852/ ejt.2017.345

\section{Introduction}

The Wanganui Basin, located in southwestern North Island, New Zealand, contains one of the most complete late Neogene marine stratigraphic records in the world (Carter \& Naish 1998). It is a fossilrich, proto-back-arc basin containing a thick sequence of Plio-Pleistocene siliciclastic sediments 
deposited in shallow shelf environments. Compound shellbeds alternate with siliciclastic facies, the mollusc shells present offering substrata for a rich and diverse bryozoan fauna (Rust \& Gordon 2011). The first report of bryozoans from Wanganui is found in Waters (1887), who described the bryozoan fauna of the Castlecliffian Tainui Shellbed at Shakespeare Cliff, sent to him by the collector F.W. Hutton. Later, Brown (1952) described 32 cheilostome species from the Nukumaruan Mangamako horizon near Hunterville and Castlecliffian strata at Shakespeare Cliff and Castlecliff collected by C.A. Fleming in 1948. In this work, he revised the nomenclature of Waters' specimens in the Hincks and Vine collections in the British Museum (Natural History) and in the Waters and Jelly collections at Manchester Museum.

Recent and more comprehensive studies in the Wanganui Basin by Rust (2009) and Rust \& Gordon (2011) reported 103 species, comprising 77 cheilostomes and 26 cyclostomes, the majority still alive today on the continental shelf around New Zealand. In this context, Gordon et al. (2009) reported that $65 \%$ of the Pliocene bryozoan species of New Zealand are still extant. Ongoing research focusing on ecological interactions among bryozoans from the Wanganui Basin (Liow et al. 2016, 2017) has prompted taxonomic revision for some taxa (e.g., Di Martino et al. 2016), resulting in a reduction of this percentage. In addition, these studies have revealed the presence of three new species, which are described here: Buskia waiinuensis sp. nov., a ctenostome preserved by bioimmuration; Microporella rusti sp. nov., an ascophoran-grade cheilostome previously indicated as new by Rust (2009) and Rust \& Gordon (2011), but not formally described; and Parkermavella columnaris sp. nov., another ascophoran, a specimen of which has also been found at the present-day encrusting a bivalve.

\section{Material and methods}

This study is based on both fossil and Recent material from New Zealand. Fossil specimens were collected in March 1996 and January 2014 from coastal cliffs located west of the city of Wanganui. A Recent colony of Parkermavella columnaris sp. nov. was coincidentally found in the NIWA Invertebrate Collection, National Institute of Water \& Atmospheric Research, Wellington; its provenance is uncertain, but likely to have been in the greater Cook Strait area. Holotypes of the fossils are deposited in the collection of the Institute of Geological and Nuclear Sciences (GNS), Lower Hutt, New Zealand and other specimens in the palaeontological collection of the Natural History Museum, London (NHMUK), while Recent material is housed at NIWA.

For further comparison, specimens of putative Microporella hyadesi (Jullien, 1888) (NHMUK D3679636797) from the Waiauan (Middle Miocene) of Southland, and the holotype (NHMUK D36809) and paratype (NHMUK D36806) of Microporella ordo (Brown, 1952) from the Pleistocene of Castlecliff were studied and are figured here using SEM for the first time.

Uncoated specimens were studied using a LEO 1455VP SEM at NHMUK and a Hitachi TM3000 Tabletop SEM at NIWA. Linear measurements were made from SEM images using the image processing software ImageJ. These are given as the total number of measurements made $(\mathrm{N})$, mean in microns plus/minus standard deviation (SD), and observed range (Min and Max). Measurements are abbreviated as follows:

$$
\begin{aligned}
\mathrm{ZL} & =\text { zooid length } \\
\mathrm{ZW} & =\text { zooid width } \\
\mathrm{OL} & =\text { orifice length } \\
\mathrm{OW} & =\text { orifice width } \\
\mathrm{OvL} & =\text { ooecium length } \\
\mathrm{OvW} & =\text { ooecium width } \\
\mathrm{AvL} & =\text { avicularium length } \\
\mathrm{AvW} & =\text { avicularium width }
\end{aligned}
$$




\title{
Results
}

\author{
Phylum Bryozoa Ehrenberg, 1831 \\ Class Gymnolaemata Allman, 1856 \\ Order Ctenostomata Busk, 1852 \\ Superfamily Vesicularioidea Hincks, 1880 \\ Family Buskiidae Hincks, 1880 \\ Genus Buskia Alder, 1856 \\ Buskia waiinuensis sp. nov. \\ urn:1sid:zoobank.org:act:A5EC216B-6E64-4A39-A77E-47EA338DDF53
}

Fig. 1, Table 1

\section{Diagnosis}

Colony encrusting, with a stolonal system branching at variable angles. Stolons thick, showing concentric lines. One or two zooids per internode, elongated elliptical, with the frontal surface convex and showing concentric lines. Orifice circular or oval, with one or two lateral cystid appendages.

\section{Etymology}

From Waiinu Beach, the type locality.

\section{Material examined}

\section{Holotype}

NEW ZEALAND: Nukumaru Limestone, Waiinu Beach (R22/f0270), Nukumaruan, Pleistocene (GNS BZ 335).

\section{Description}

Colony entirely encrusting, consisting of a somewhat variable ramifying stolonal system with sidebranches given off stolonal axis dichotomously, at $45^{\circ}$ or at $90^{\circ}$, forming square or rectangular sectors (Fig. 1A-B). Stolons apparently fused at contact point with one another, thick, 50-65 $\mu \mathrm{m}$ in diameter. Stolonal walls shallow, ornamented with very thin, closely spaced, concentric lines. Zooids sparsely distributed (Fig. 1A-B), irregularly positioned, usually one or two per stolonal internode, oriented with long axis parallel or perpendicular to stolonal axis, depending on overgrowth direction, elliptical, elongated and narrow (mean $\mathrm{L} / \mathrm{W}=2.72$ ). Frontal surface evenly curved and slightly convex, ornamentation similar to that of stolons but with thicker concentric lines (Fig. 1C-D). Orifice circular or transversely oval (Fig. 1C-D). One or two cystid appendages visible laterally to orifice (Fig. 1C-D), $58-68 \mu \mathrm{m}$ long.

\section{Remarks}

Four fossil species of Buskia have been described, all preserved by bioimmuration and from European localities. In order of stratigraphic age these are: B. nigribovis Todd, 1994 from the Jurassic of France, B. inexpectata Voigt, 1979 from the Maastrichtian of the Netherlands, B. fowleri Todd, 1996 from the Eocene of England and B. hachti Voigt, 1979 from the Pliocene of France. At the present day, Buskia is represented in New Zealand by two non-indigenous species that are considered as established, viz $B$. nitens Alder, 1856 and B. socialis Hincks, 1887 (Gordon \& Mawatari 1992; Gordon et al. 2009).

Buskia waiinuensis sp. nov. differs from B. nigribovis in being regularly ramifying, with much thicker stolons $(50-65 \mu \mathrm{m}$ vs $14-24 \mu \mathrm{m})$ and a limited number of cystid appendages. The latter character also distinguishes the new species from $B$. fowleri, which in addition has densely populated stolons, as 
Table 1. Measurements in microns of Buskia waiinuensis sp. nov., Nukumaruan, Pleistocene, Nukumaru Limestone.

\begin{tabular}{cccccc}
\hline & N (zooids, colonies) & Mean & SD & Min & Max \\
\hline ZL & 8,1 & 380 & \pm 54 & 308 & 438 \\
ZW & 8,1 & 140 & \pm 13 & 121 & 149 \\
OL & 8,1 & 66 & \pm 9 & 53 & 76 \\
OW & 8,1 & 77 & \pm 7 & 70 & 86 \\
\hline
\end{tabular}

does B. inexpectata. Buskia hachti has a stolon width similar to that of the new species (ca $50 \mu \mathrm{m}$ ), but more elongated zooids $(400-650 \mu \mathrm{m}$ vs $308-438 \mu \mathrm{m})$ and no cystid appendages. Of the two Recent species present in New Zealand, B. socialis differs in being erect, while B. nitens has narrower stolons (ca $25 \mu \mathrm{m}$ ).
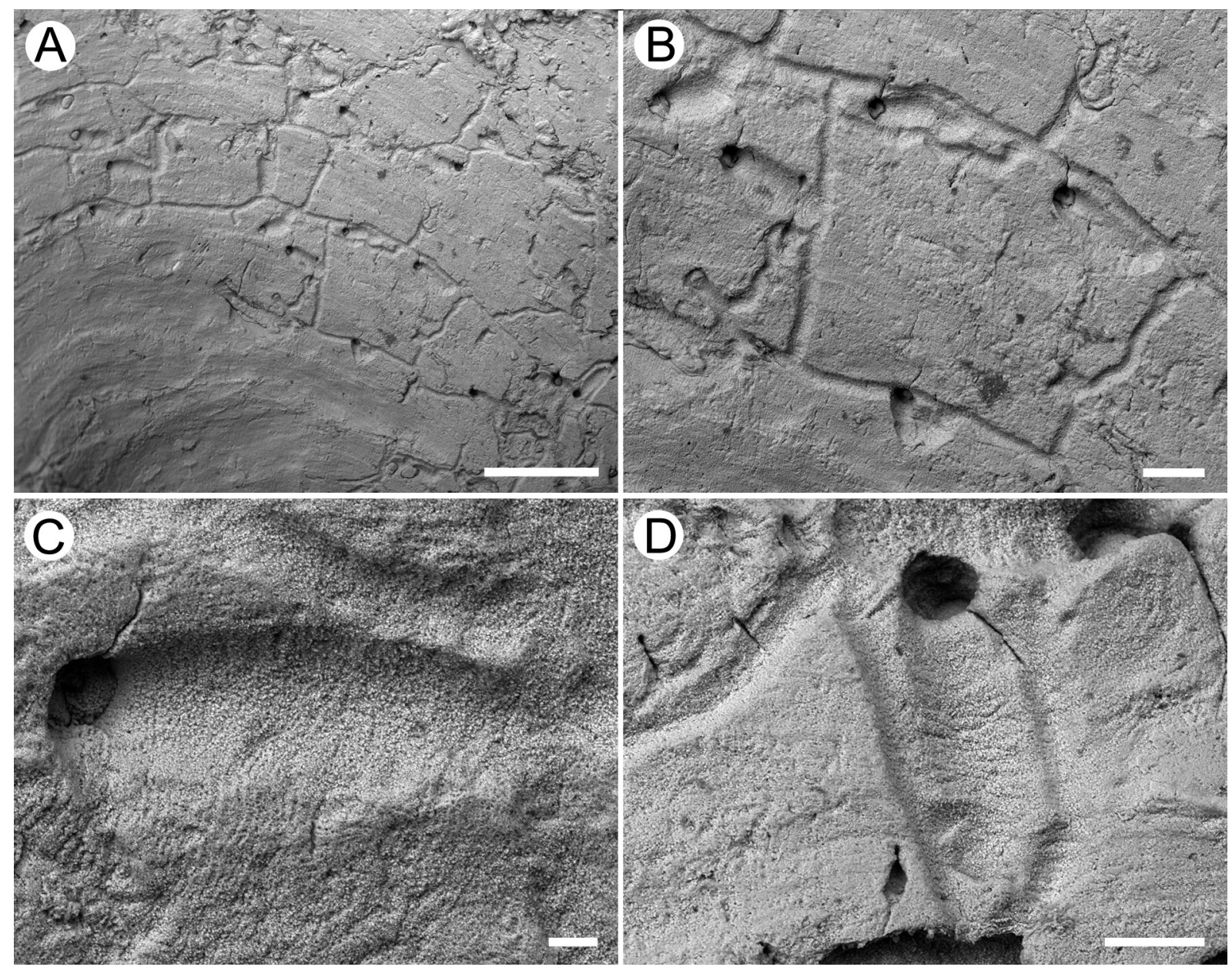

Fig. 1. Buskia waiinuensis sp. nov., holotype (GNS BZ 335), Nukumaruan, Pleistocene, Nukumaru Limestone, Waiinu Beach, New Zealand. A. General view of the bioimmured colony, showing the regular development of the stolonal pattern. B. Close-up of a sector of the colony. C. Close-up of a zooid with oval orifice. Note the cystid appendage lateral to the orifice and the concentric lines on the zooidal and stolonal surface. D. Close-up of a zooid with a circular orifice and two cystid appendages lateral to the orifice. Scale bars: A $=1 \mathrm{~mm} ; \mathrm{B}=200 \mu \mathrm{m} ; \mathrm{C}=50 \mu \mathrm{m} ; \mathrm{D}=100 \mu \mathrm{m}$. 


\title{
Distribution
}

The single known bioimmured colony is preserved as a mould bioimmuration on the underside of an erect cyclostome bryozoan which overgrew the soft-bodied ctenostome. It was collected from the Nukumaru Limestone (2.29-2.08 Ma, Nukumaruan, Pleistocene) at Waiinu Beach and represents the first fossil record of the genus outside Europe.

\author{
Order Cheilostomata Busk, 1852 \\ Superfamily Smittinoidea Levinsen, 1909 \\ Family Bitectiporidae MacGillivray, 1895 \\ Genus Parkermavella Gordon \& d'Hondt, 1997 \\ Parkermavella columnaris sp. nov. \\ urn:1sid:zoobank.org:act:D3D59208-F73C-4A9A-960A-12A042FCB8EE
}

Figs 2-3, Tables 2-3

\section{Diagnosis}

Colony encrusting. Autozooids polygonal. Frontal shield partially umbonuloid, smooth and imperforate centrally, with a continuous row of marginal areolar pores. Orifice broadly cleithridiate (keyhole shaped), with condyles delimiting the arched anter from a broad sinus. Distal oral spines present. A columnar structure bearing an adventitious suboral avicularium with a complete crossbar constantly present. Ooecium lepralielliform; ectooecium calcified, smooth, with pseudopores; secondary calcification of the frontal shield of the distal zooid covering the distal half of the ooecium and bearing an avicularium similar to the suboral one.

\section{Etymology}

From the Latin columnaris, -e, pillar-like, referring to the columnar peristome bearing the suboral avicularium.

\section{Material examined}

\section{Holotype}

NEW ZEALAND: Recent, ?Cook Strait (NIWA 97418).

\section{Paratypes}

NEW ZEALAND: Upper Kai-Iwi Shellbed, Castlecliff Beach, Castlecliffian, Pleistocene (NHMUK PI BZ 7832, NHMUK PI BZ 7833).

\section{Description}

Colony encrusting, small in fossil colonies, up to $33 \mathrm{~mm}$ in diameter in Recent holotype colony. Ancestrula and early astogeny not observed. Autozooids arranged in parallel rows (Figs 2A, 3A), varying in shape, commonly rectangular, sometimes hexagonal or irregularly polygonal, longer than broad (mean $\mathrm{L} / \mathrm{W}=$ 1.29). Frontal shield partially umbonuloid, convex centrally, flat proximally, smooth and imperforate apart from a continuous row of numerous large $(20-35 \mu \mathrm{m})$, evenly distributed areolar pores, usually 7-9 along lateral and distal margins, oval to circular, funnel-shaped or sloping outward. Sometimes, one or two additional areolar pores form a second row in distolateral corners of zooids. Orifice broadly cleithridiate (Figs 2B, 3B). Two small, pointed, downward-directed condyles placed at two thirds of orifice length, separating an arched anter from a broad, shallow, bowl-shaped sinus. Two, three or four oral spine bases (10-22 $\mu \mathrm{m}$ in diameter) placed on distal orificial margin, hidden in ovicellate zooids. Peristome developed as two lateral wings, rising proximally, forming a somewhat columnar structure, rising $150-160 \mu \mathrm{m}$ from surface of frontal shield in lateral view, always bearing a suboral avicularium 
(Fig. 2C). Peristome hiding primary orifice in frontal view. Adventitious avicularium suboral, small, oval, upward-directed, sloping distally, rostrum rounded and with a complete crossbar (Figs 2B, 3B-C). Ooecia of lepralielliform type, prominent and globular (Figs 2A, 3C). Ectooecium calcified, smooth, centrally perforated, pseudopores bordered by a raised margin, varying in size (10-30 $\mu \mathrm{m})$ and form from circular to bean-shaped. Secondary calcification from frontal shield of distal zooid covers distal half of ooecium, forming a raised crest bearing an avicularium similar in size and shape to suboral avicularium. The two avicularia aligned, but oppositely directed.

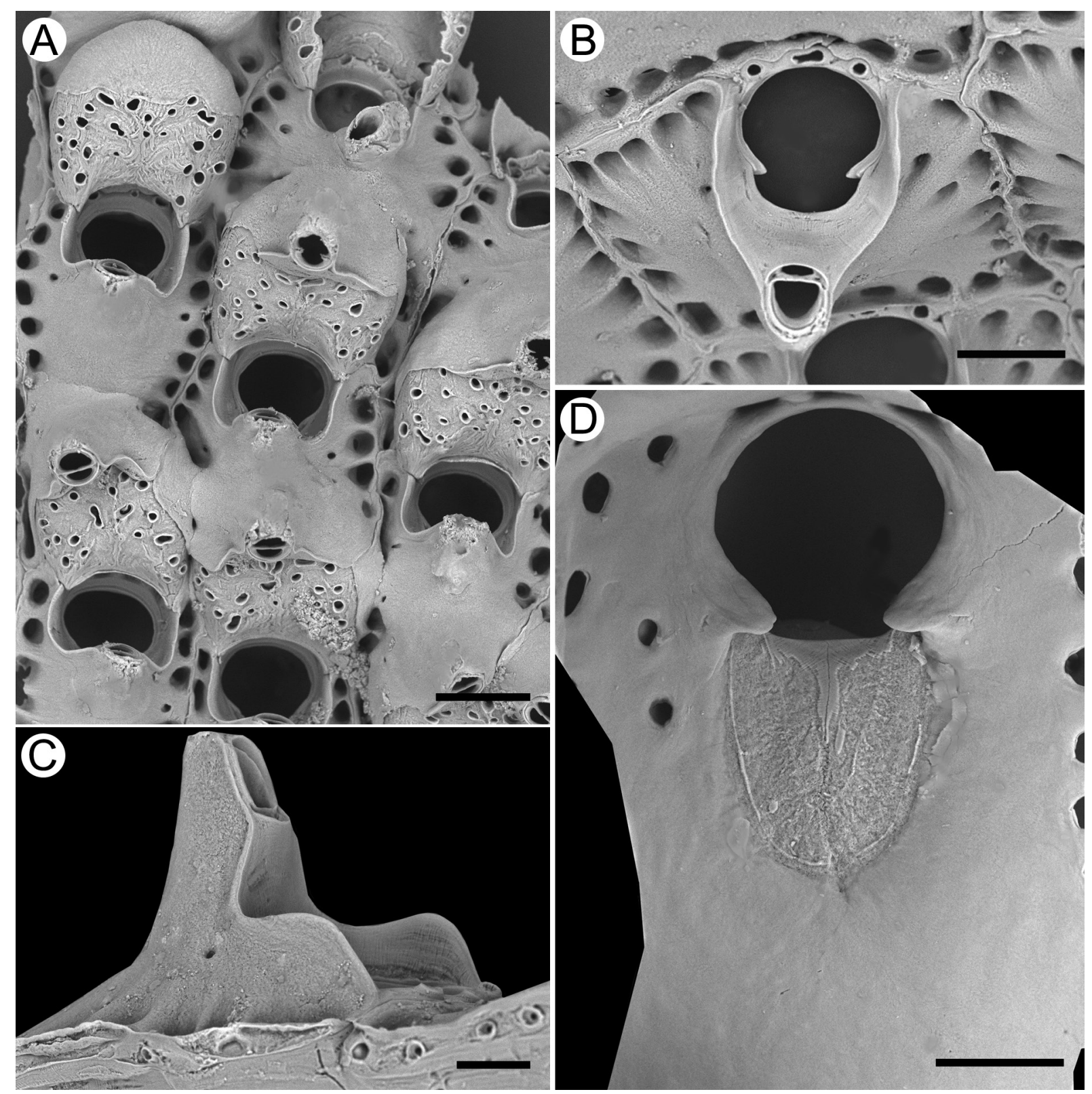

Fig. 2. Parkermavella columnaris sp. nov., holotype (NIWA 97418), Recent, inferred greater Cook Strait, New Zealand. A. Group of ovicellate zooids. B. Tilted close-up of an autozooid showing the broadly cleithridiate (keyhole shaped) orifice, four distal oral spines, two of which coalescent, and the suboral avicularium with complete cross-bar. C. Lateral view of the columnar peristome bearing the suboral avicularium. D. Inner view of the frontal shield showing the umbonuloid area and ring scar. Scale bars: $\mathrm{A}=250 \mu \mathrm{m} ; \mathrm{B}=100 \mu \mathrm{m} ; \mathrm{C}-\mathrm{D}=50 \mu \mathrm{m}$. 
Table 2. Measurements in microns of Parkermavella columnaris sp. nov., Recent, New Zealand (inferred greater Cook Strait).

\begin{tabular}{cccccc}
\hline & N (zooids, colonies) & Mean & SD & Min & Max \\
\hline ZL & 4,1 & 428 & \pm 53 & 372 & 496 \\
ZW & 4,1 & 333 & \pm 39 & 285 & 376 \\
OL & 4,1 & 126 & \pm 7 & 116 & 133 \\
OW & 4,1 & 124 & \pm 9 & 111 & 133 \\
OvL & 6,1 & 223 & \pm 18 & 206 & 252 \\
OvW & 6,1 & 239 & \pm 23 & 194 & 260 \\
AvL & 4,1 & 67 & \pm 8 & 56 & 75 \\
AvW & 4,1 & 60 & \pm 4 & 55 & 64 \\
\hline
\end{tabular}
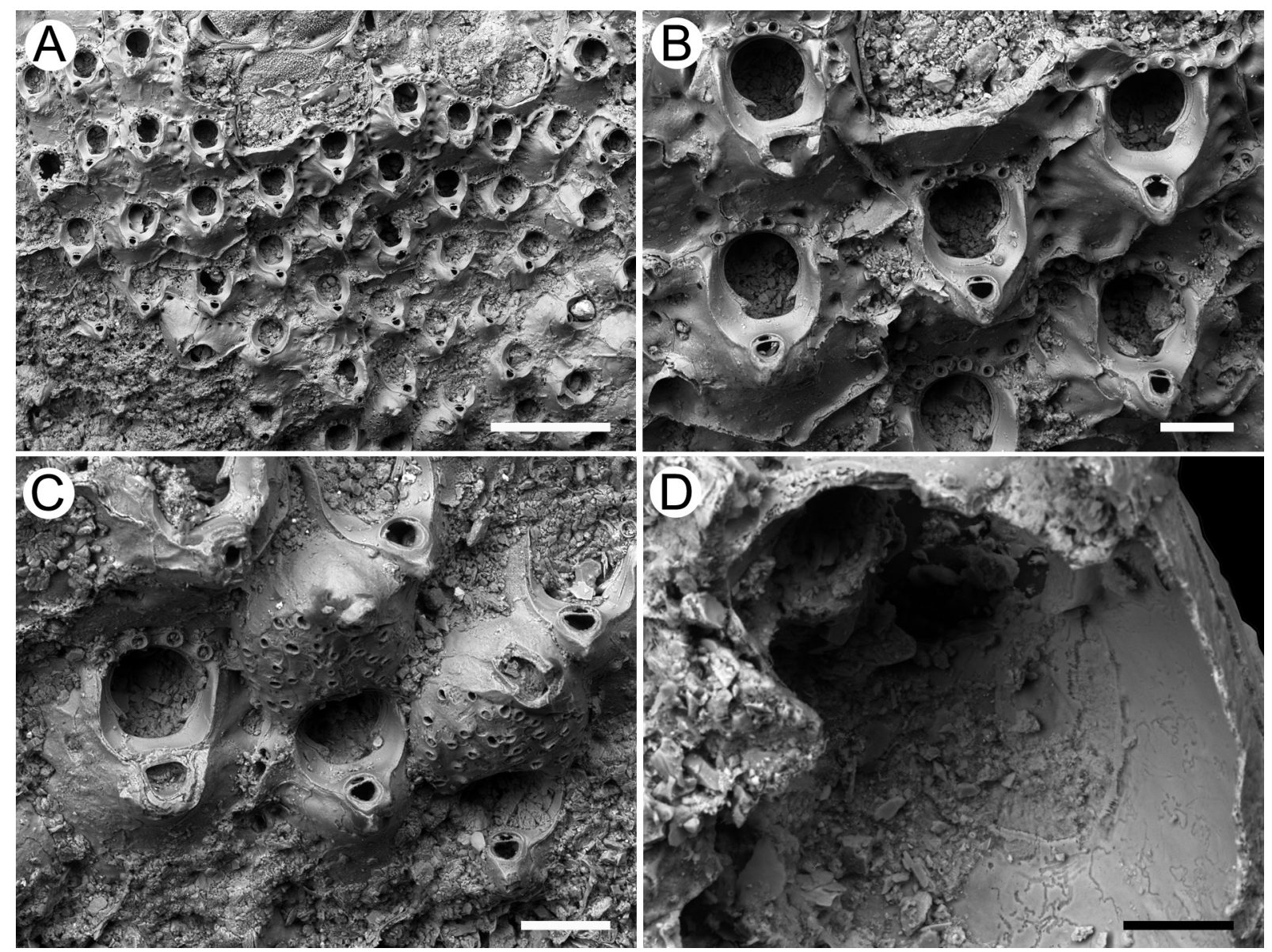

Fig. 3. Parkermavella columnaris sp. nov. A-C. Paratype (NHMUK PI BZ 7832), Castlecliffian, Pleistocene, Upper Kai-Iwi Shellbed, New Zealand. A. View of a small colony. B. Group of autozooids. C. Two ovicellate zooids. D. Paratype (NHMUK PI BZ 7833), same provenance as preceding, inner view of the frontal shield showing part of the ring scar bordering the umbonuloid area. Scale bars: $\mathrm{A}=500 \mu \mathrm{m} ; \mathrm{B}-\mathrm{C}=100 \mu \mathrm{m} ; \mathrm{D}=50 \mu \mathrm{m}$. 
Table 3. Measurements in microns of Parkermavella columnaris sp. nov., Castlecliffian, Pleistocene, Upper Kai-Iwi Shellbed.

\begin{tabular}{cccccc}
\hline & N (zooids, colonies) & Mean & SD & Min & Max \\
\hline ZL & 10,1 & 313 & \pm 33 & 256 & 370 \\
ZW & 10,1 & 242 & \pm 35 & 191 & 305 \\
OL & 8,1 & 106 & \pm 3 & 100 & 110 \\
OW & 8,1 & 92 & \pm 4 & 86 & 97 \\
OvL & 2,1 & 186 & \pm 4 & 183 & 189 \\
OvW & 2,1 & 214 & \pm 5 & 210 & 217 \\
AvL & 18,1 & 65 & \pm 10 & 47 & 83 \\
AvW & 18,1 & 54 & \pm 7 & 42 & 65 \\
\hline
\end{tabular}

\section{Remarks}

Parkermavella was introduced by Gordon \& d'Hondt (1997) for Schizomavella-like species with frontal shields imperforate apart from marginal areolar pores. In the diagnosis of the genus (Gordon \& d'Hondt 1997: 17), the zooids are defined as lepralioid; however, new observations have revealed, for at least some of the species, the presence of an umbonuloid area of variable size. For instance, in P. curvata (Uttley \& Bullivant, 1972) the umbonuloid area is large, occupying most of the frontal shield, while in P. punctigera (MacGillivray, 1883) and P. virago (Gordon, 1989) it is more reduced, slightly smaller than the orifice in the former species and about the size of the orifice in the latter species (D.P.G., personal observation). In P. columnaris sp. nov. the umbonuloid area is small (Figs 2D, 3D), $120 \mu \mathrm{m}$ long by $95 \mu \mathrm{m}$ wide, and possibly coincides with the overlying avicularian cystid.

This genus is moderately diverse in New Zealand waters at the present day, with seven species formally described from the region and several others awaiting description (D.P.G., unpublished data). The new species is easily distinguishable from all other known species of Parkermavella by its unique suite of morphological characters, specifically the smooth frontal shield (nodular-tubercular in many other species), the broadly keyhole-shaped orifice with a large and concave sinus (narrow and/or straight in the others), and the unique columnar structure bearing the suboral avicularium. P. virago (Gordon, 1989) has a similar smooth frontal shield and development of the secondary calcification of the distal zooid covering the ooecia, but differs in the more numerous, smaller avicularia suborally and in the secondary calcification.

The sole Recent colony of $P$. columnaris sp. nov. differs from the fossil ones in having slightly larger zooids, orifices and ooecia, although the $\mathrm{L} / \mathrm{W}$ ratio is identical (Tables 2-3).

\section{Distribution}

The oldest geological record of this species dates back to the Nukumaruan (2.29-2.08 Ma, Pleistocene) of the Wanganui Basin. A small number of colonies were found encrusting bivalve shells from the Nukumaru Limestone, and on bivalve shells of the Castlecliffian Upper Kai-Iwi Shellbed (0.68-0.62 Ma, Pleistocene). The Recent colony of Parkermavella columnaris sp. nov. housed in the NIWA collection (i.e., the holotype) unfortunately lacks collection data. It encrusts a $75 \mathrm{~mm}$-long valve of the pholadid bivalve Barnea similis (Gray, 1835), along with the bryozoans Antarctothoa bathamae (Ryland \& Gordon, 1977), A. tongima (Ryland \& Gordon, 1977), Caberea rostrata Busk, 1884, Chaperiopsis lanceola Hayward \& Thorpe, 1988, Cornuticella taurina (Busk, 1852), Opaeophora lepida (Hincks, 1881), Orthoscuticella fissurata (Levinsen, 1909) and Tricellaria aculeata (d'Orbigny, 
DI MARTINO E. et al., New bryozoans from Wanganui

Table 4. Measurements in microns of Microporella rusti sp. nov., Nukumaruan, Pleistocene, Nukumaru Limestone.

\begin{tabular}{cccccc}
\hline & N (zooids, colonies) & Mean & SD & Min & Max \\
\hline ZL & 20,2 & 453 & \pm 56 & 337 & 547 \\
ZW & 20,2 & 372 & \pm 81 & 254 & 567 \\
OL & 20,2 & 64 & \pm 4 & 56 & 72 \\
OW & 20,2 & 118 & \pm 8 & 103 & 134 \\
AvL & 10,2 & 90 & \pm 7 & 81 & 102 \\
AvW & 10,2 & 70 & \pm 7 & 56 & 80 \\
\hline
\end{tabular}

1842). The known distributions of these species (Gordon 1986, 1989) overlap or coincide only in greater Cook Strait, a provenance correlated with the presence there of rocks bored by pholadids; hence we conclude that the holotype specimen came from a locality in the greater Cook Strait area.

$$
\begin{gathered}
\text { Superfamily Schizoporelloidea Jullien, } 1883 \\
\text { Family Microporellidae Hincks, } 1879 \\
\text { Genus Microporella Hincks, } 1879 \\
\text { Microporella rusti sp. nov. } \\
\text { urn:1sid:zoobank.org:act:95F31C54-CEAA-41A4-964B-9848063DE6D6 }
\end{gathered}
$$

Fig. 4, Table 4

\section{Diagnosis}

Colony large, encrusting. Autozooids hexagonal, with coarsely granular and perforated frontal shield. Marginal areolar pores conspicuous. Orifice semielliptical. Oral spines absent. Ascopore crescentic and finely toothed, with a proximal saucer-shaped rim. Avicularia rare, usually single, directed distally or distolaterally, proximal edge level with or proximal to the ascopore. Ovicell unknown.

\section{Etymology}

Named after Dr Seabourne Rust for his important contributions to the knowledge of fossil bryozoans from the Wanganui Basin.

\section{Material examined}

Holotype

NEW ZEALAND: Nukumaru Limestone, Waiinu Beach, Nukumaruan, Pleistocene (GNS BZ 336).

\section{Paratypes}

NEW ZEALAND: same collection data as for holotype (NHMUK PI BZ 7834, NHMUK PI BZ 7835).

\section{Description}

Colony encrusting, large, unilaminar (Fig. 4A). Ancestrula similar to later autozooids but smaller, about $230 \mu \mathrm{m}$ long by $180 \mu \mathrm{m}$ wide, budding one distal and two distolateral autozooids, surrounded by six autozooids (Fig. 4D). Later autozooids arranged quincuncially, hexagonal, longer than broad (mean $\mathrm{L} / \mathrm{W}=1.22)$, with shallow interzooidal furrows, varying in size, some very narrow $(\mathrm{ZW}=250-300 \mu \mathrm{m})$, others broad, almost as wide as long $(\mathrm{ZW}=550-570 \mu \mathrm{m})$, usually located at colony bifurcations, their width equivalent to the two or three distal zooids succeeding them (Fig. 4E). Frontal shield convex, 
coarsely granular, with small (about 5-10 $\mu \mathrm{m}$ ), sparse, circular pseudopores varying in number, numerous in some zooids (approximately 50-60) but fewer seen in others, perhaps because of concealment by diagenetic cement or sediment particles. Marginal areolar pores conspicuous, about 40-55 $\mu \mathrm{m}$ long,
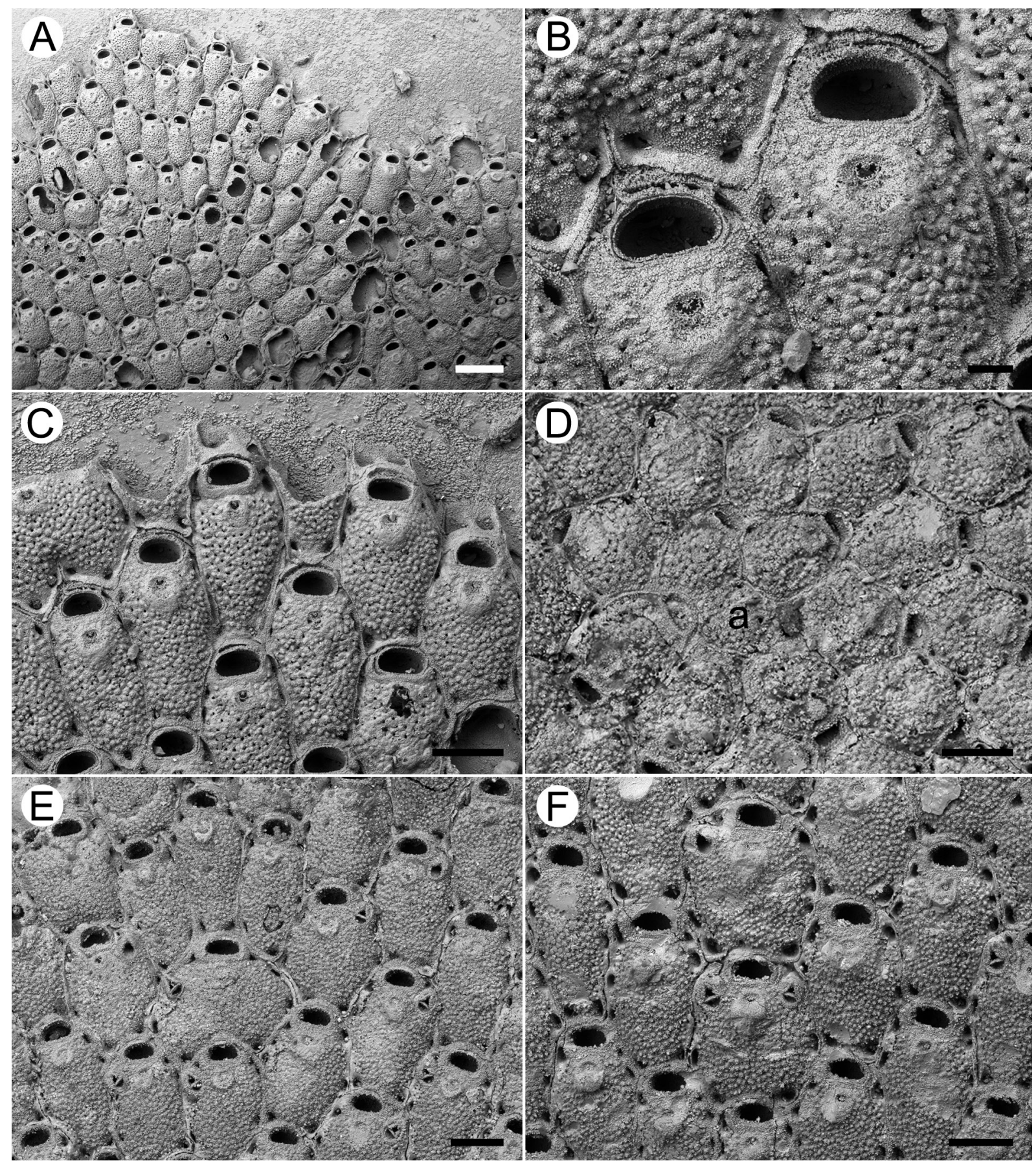

Fig. 4. Microporella rusti sp. nov. A-C. Holotype (GNS BZ 336), Nukumaruan, Pleistocene, Nukumaru Limestone, Waiinu Beach, New Zealand. A. View of two colonies growing side by side. B. Close-up of two autozooids lacking avicularia, showing the orifice and ascopore. C. Close-up of zooids at the growing edge. D. Paratype (NHMUK PI BZ 7834), same provenance as holotype, showing ancestrula (a) and early astogeny. E-F. Paratype (NHMUK PI BZ 7835), same provenance as holotype. E. Group of zooids. Note the large zooid at the centre preceding row division. F. Group of zooids. Note the zooid at the centre bearing two avicularia. Scale bars: $A=500 \mu \mathrm{m} ; \mathrm{B}=50 \mu \mathrm{m} ; \mathrm{C}-\mathrm{F}=200 \mu \mathrm{m}$. 
slit-like, at least six per zooid, located at each corner, sometimes with an additional one along distal and lateral zooidal margins. Orifice distally placed, semielliptical or transversely D-shaped, surrounded by a slightly raised and thick margin, wider than long (Fig. 4B). Oral spines absent. Ascopore located in distal part of an ascopore field below orifice, small, crescentic, finely toothed (Fig. 4B). Ascopore field surrounded by a smooth rim, higher and wider proximally, forming a saucer-shaped structure often levelled off (Fig. 4E-F). Avicularia rare, usually single, only once observed paired (Fig. 4F), small, located on distolateral zooidal margin, roughly at same level as ascopore or slightly distal or proximal, triangular, with pointed rostrum directed distally or distolaterally and complete crossbar. Ovicells not observed in any of more than one hundred colonies studied, presumed absent at least in the fossil populations studied.

\section{Remarks}

Microporella is one of the most species-rich cheilostome genera, with an increasing number of new species having been recognized since the availability of SEM, which has allowed subtle differences in skeletal morphology to be observed (Taylor \& Mawatari 2005). Six species, Recent and fossil, have their type occurrence in New Zealand (based on http://www.bryozoa.net, accessed 16 May 2016) and many others have a wider distribution that includes New Zealand. Among Cenozoic species reported previously from the area, M. ordo Brown, 1952 and nominal M. hyadesi (Jullien, 1888) lack oral spines. Microporella ordo (Fig. 5) was described from the Wanganui Basin at Castlecliff (about 0.55 Ma, Castlecliffian, Late Pleistocene) and differs from the new species in having more numerous marginal areolar pores, a frontal shield with a coarser granulation and more-numerous and larger pseudopores, larger and constant avicularia, the proximal orificial margin with a coarse denticulation, a reticulate ascopore, and zooids arranged in well defined longitudinal rows. Microporella hyadesi (Fig. 6), first described from Recent material from Cape Horn and the Falkland Islands, was reported by Brown (1952: 257) from several New Zealand localities of Middle Oligocene to Pliocene age. It is likely that M. hyadesi sensu Brown (1952) is a closely related species but distinct from the nominal species (Rust 2009). It differs from M. rusti in having ovicells, often paired smaller avicularia, a smaller orifice, a reticulate ascopore and no obvious marginal pores at the zooidal corners.
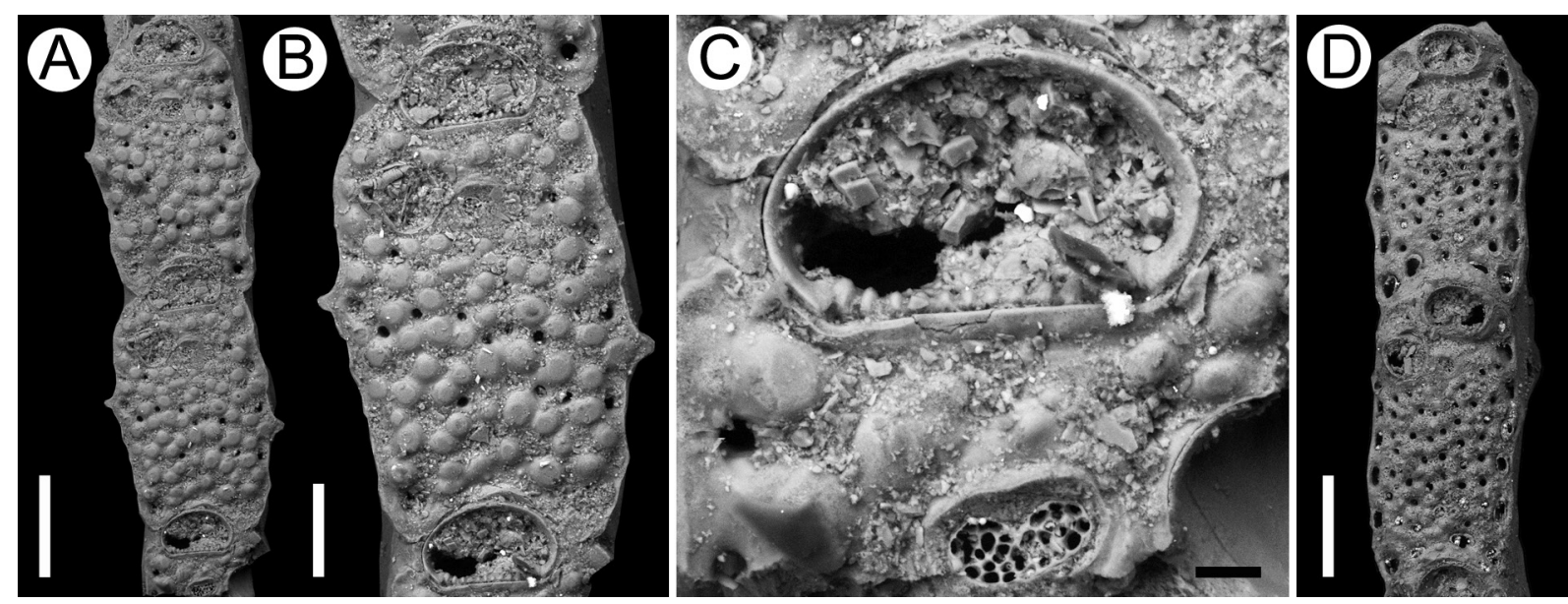

Fig. 5. Microporella ordo Brown, 1952. A-C. Holotype (NHMUK D36809), Wanganui, Castlecliffian Horizon CU3, Pleistocene, NZGS Loc. 4013 Castlecliff, New Zealand. A. Frontal view of the linear colony fragment. B. Close-up of an autozooid. C. Close-up of the orifice and ascopore. D. Paratype (NHMUK D36806), same provenance as holotype, view of the linear colony fragment. Scale bars: $\mathrm{A}, \mathrm{D}=200 \mu \mathrm{m} ; \mathrm{B}=100 \mu \mathrm{m} ; \mathrm{C}=20 \mu \mathrm{m}$. 


\section{Distribution}

Common in the Nukumaru Limestone (2.29-2.08 Ma, Nukumaruan, Pleistocene) and the Nukumaru Brown Sand (2.03-1.97 Ma, Nukumaruan, Pleistocene) encrusting bivalve shells, often associated with Anomia trignopsis Hutton, 1877 (Rust 2009). Rare in Castlecliffian (0.58-0.52 Ma, Pleistocene) strata.

\section{Discussion}

The Plio-Pleistocene of the Wanganui Basin contains rich bryozoan faunas that are currently being studied as exemplars of the macroevolutionary dynamics of ecological interactions through geological time (Liow et al. 2016, 2017). While the taxonomy of the cyclostomes in the sequences has received little attention for evaluation, it is apparent that most of the cheilostomes present are species still living in New Zealand waters. These include a new species of Parkermavella, P. columnaris sp. nov., introduced here based on both Recent and fossil material. Another new cheilostome, Microporella rusti sp. nov., is as yet unknown at the present day, as is a soft-bodied ctenostome, Buskia waiinuensis sp. nov., preserved as a bioimmured natural mould on the underside of the cyclostome bryozoan that overgrew it.

The enigmatic absence of ovicells in Microporella rusti sp. nov. is noteworthy. Ovicells have been described in most species of Microporella, though not all (e.g., M. antarctica Hu \& Wang, 1984, M. cucullata Canu \& Bassler, 1928, and M. franklini Soule, Chaney \& Morris, 2003). More than a hundred large colonies of M. rusti sp. nov. (often containing more than a hundred zooids) have been studied here, none of them showing any sign of external brooding structures. The absence of ovicells was also noted by Rust (2009) in his material collected from the same area. Given the large number of specimens observed, we presume that the lack of ovicells is real and not a sampling bias. Several hypotheses can be proposed to explain the absence of ovicells in this species: (1) the species is an internal brooder; (2) the studied Wanganui Basin populations were non-breeding and were sourced from breeding populations of $M$. rusti sp. nov. living elsewhere; (3) material described here as M. rusti sp. nov. comprises only male colonies, female colonies being sufficiently different to be identified as a distinct species.
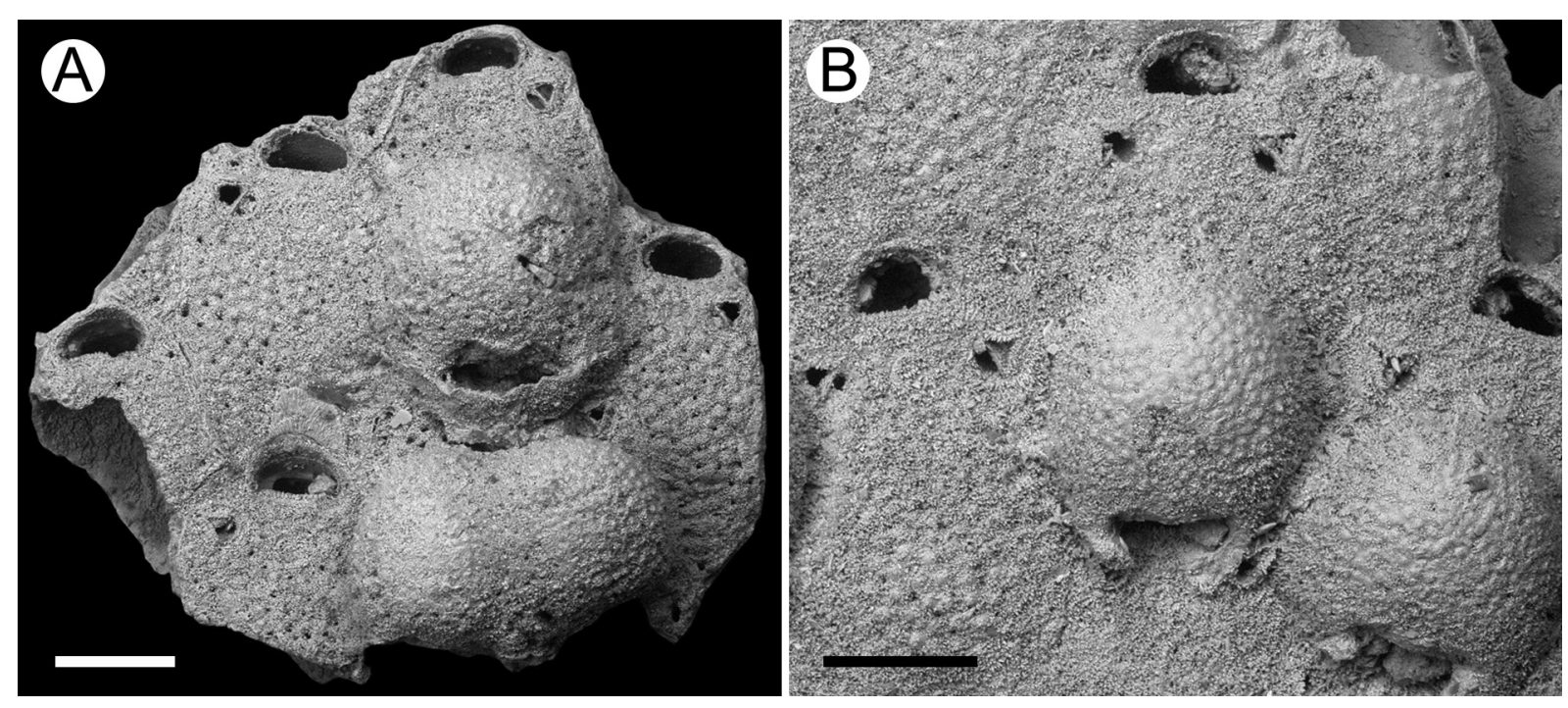

Fig. 6. Microporella hyadesi (Jullien, 1888) sensu Brown 1952 (NHMUK D36796 and D36797), Southland, Waianan, Middle Miocene, base of the uppermost Mt. Brown "E" Limestone, Junction of Weka Creek, Weka Pass Stream, Waipara, Canterbury, New Zealand. Two colony fragments including autozooids and ovicellate zooids. Scale bars $=200 \mu \mathrm{m}$. 
Regarding hypothesis (1), there is no literature record of internal brooding within Microporella, although descriptions and figures of ovicells are lacking for a significant number of species assigned to the genus, as already noted. We carefully checked for any feature that may indicate internal brooding in M. rusti sp. nov., notably dimorphic orifices and dimorphic zooids, but none was found. Scattered, larger zooids were observed, but their position shows that they are related to row bifurcations (e.g., Fig. 4C). A specimen was ground down to look beneath the frontal shield, but no sign of any internal brooding structure was evident. As internal brooding tends to correlate with large zooid size in cheilostomes, we compared the size of zooids (mean ZL) in M. rusti sp. nov. with 56 fossil and Recent species of Microporella known to possess ovicells, and for which zooidal size has been reported in the literature (Fig. 7). With a mean ZL of $0.453 \mathrm{~mm}$, M. rusti sp. nov. falls within the smallest size category, a finding that does not support the internal brooding hypothesis.

The evolution from external to internal brooding requires several intermediate steps, in particular progressive sinking of the ovicell and ooecium (the skeletal part of the ovicell) beneath the colony surface (Ostrovsky 2013: 160), but these have yet to be documented in Microporella, placing a question mark over an internal brooding hypothesis for M. rusti sp. nov.

The notion that the studied populations of $M$. rusti sp. nov. were non-breeding (hypothesis 2 ) is considered unlikely in view of their high abundance and typically large colony size in the Nukumaru Limestone. As this species has yet to be found in coeval deposits in New Zealand, the existence of breeding populations elsewhere cannot be substantiated.

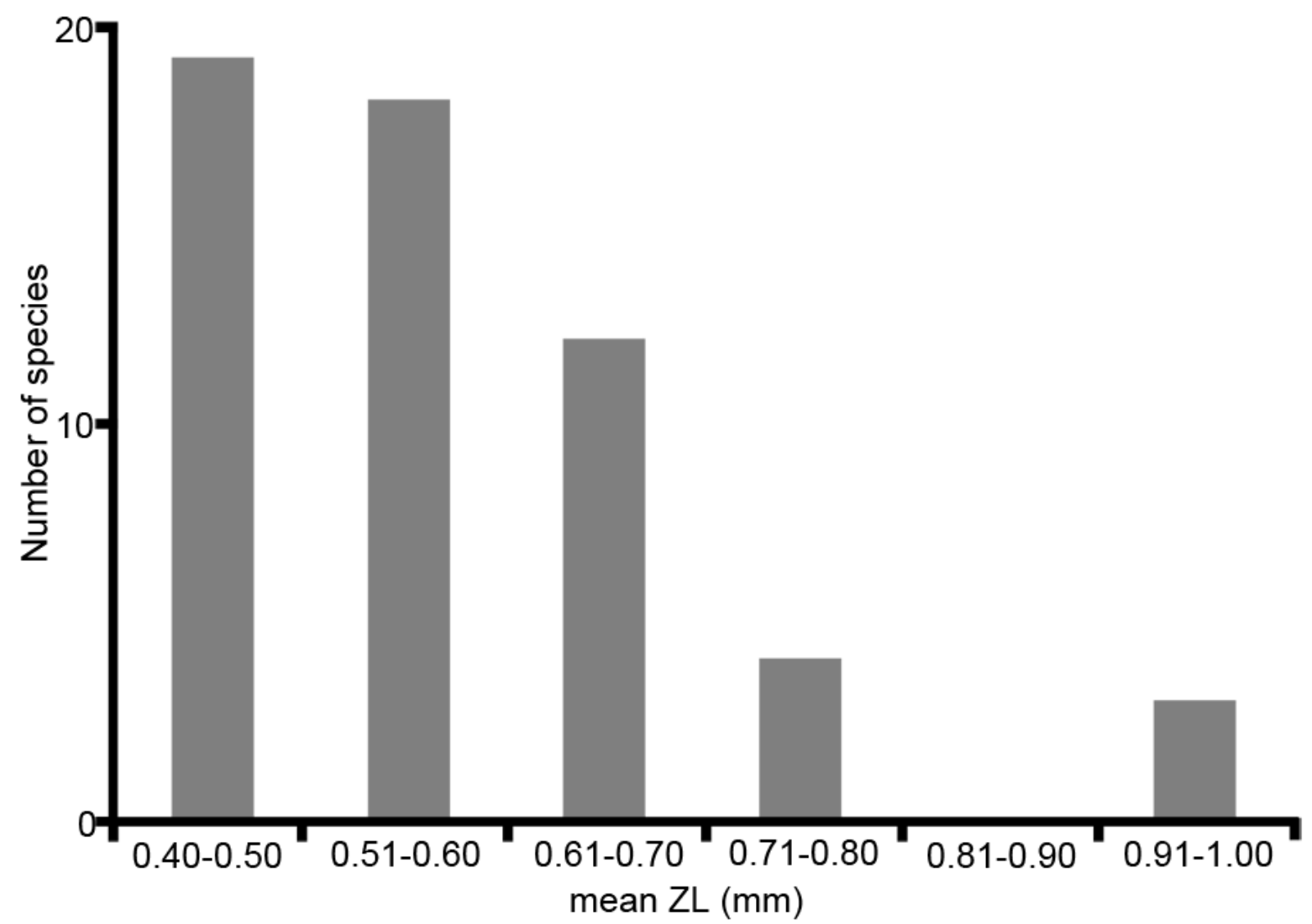

Fig. 7. Frequency distribution of zooidal size (mean ZL in $\mathrm{mm}$ ) in 56 Microporella species known to possess ovicells and for which zooidal size has been reported in the literature. 
Bryozoan colonies with separate sexes have been identified only in the cyclostome Filicrisia geniculata (Milne Edwards, 1838) (Jenkins 2013), not in the more intensively studied cheilostomes. In the case of M. rusti sp. nov., it is conceivable that our specimens are all male colonies whereas female colonies have been attributed to a different species (hypothesis 3). Only one other species of Microporella was found in the same horizon, M. agonistes Gordon, 1984, in which ovicells are present. It differs from $M$. rusti sp. nov. in having four oral spines, larger and more constant avicularia immediately subjacent to the ascopore, smaller marginal areolar pores and larger pseudopores. The contrast in skeletal morphology suggests that $M$. agonistes is only a distant relative of $M$. rusti sp. nov. and does not represent female colonies of that species. This conclusion is reinforced by the fact that M. agonistes is extant but M. rusti sp. nov. is unknown at the present-day.

Further research is required to solve the problem of the absence of ovicells in Microporella rusti sp. nov. from the Wanganui Basin.

\section{Acknowledgements}

We thank Seabourne Rust and Kjetil Lysne Voje (CEES, University of Oslo) for helping us collect some of the fossil specimens used for this study, and Consuelo Sendino and Gerardo Mazzetta (NHMUK) for curating the fossil material. NIWA is thanked for institutional support for D.P.G.'s research. Fieldwork was funded by Research Council of Norway grants 227860 and 235073. Finally, we are grateful to two anonymous reviewers for their helpful comments on the originally submitted manuscript.

\section{References}

Brown D.A. 1952. The Tertiary Cheilostomatous Polyzoa of New Zealand. Trustees of the British Museum, London.

Carter R.M. \& Naish T.R. 1998. A review of the Wanganui Basin, New Zealand: global reference section for shallow marine, Plio-Pleistocene (2.5-0 Ma) cyclostratigraphy. Sedimentary Geology 122: 37-52. https://doi.org/10.1016/S0037-0738(98)00097-9

Di Martino E., Taylor P.D., Gordon D.P. \& Liow L.H. 2016. On Powellithecidae fam. nov., a new Pliocene to Recent bryozoan family endemic to New Zealand, with the description of Powellitheca gen. nov. (Bryozoa, Cheilostomata). European Journal of Taxonomy 207: 1-17. https://doi.org/10.5852/ ejt.2016.207

Gordon D.P. 1986. The marine fauna of New Zealand: Bryozoa: Gymnolaemata (Ctenostomata and Cheilostomata Anasca) from the western South Island continental shelf and slope. New Zealand Oceanographic Institute Memoirs 95: 1-121.

Gordon D.P. 1989. The marine fauna of New Zealand: Bryozoa: Gymnolaemata (Cheilostomida Ascophorina) from the western South Island continental shelf and slope. New Zealand Oceanographic Institute Memoirs 97: 1-158.

Gordon D.P. \& d'Hondt J.-L. 1997. Bryozoa: Lepraliomorpha and other Ascophorina from New Caledonian waters. Mémoires du Muséum national d'Histoire naturelle 176: 9-124.

Gordon D.P. \& Mawatari S.F. 1992. Atlas of marine-fouling Bryozoa of New Zealand ports and harbours. New Zealand Oceanographic Institute Miscellaneous Publications 107: 1-52.

Gordon D.P., Taylor P.D. \& Bigey F.P. 2009. Phylum Bryozoa - moss animals, sea mats, lace corals. In: Gordon D.P. (ed.) New Zealand Inventory of Biodiversity. Volume One. Kingdom Animalia: Radiata, Lophotrochozoa, Deuterostomia: 271-297. Canterbury University Press, Christchurch.

Jenkins H.L. 2013. Polyembryony, Brood Chamber Development and Gender Specialisation in Cyclostome Bryozoans. PhD Thesis. Bangor University, Wales, United Kingdom. 
Liow L.H., Di Martino E., Voje K.L., Rust S. \& Taylor P.D. 2016. Interspecific interactions through 2 million years: are competitive outcomes predictable? Proceedings of the Royal Society of London B 283: e20160981. https://doi.org/10.1098/rspb.2016.0981

Liow L.H., Di Martino E., Krzeminska M., Ramsfjell M., Rust S., Taylor P.D. \& Voje K.L. 2017. Relative size predicts competitive outcome through 2 million years. Ecology Letters 20: 981-988. https://doi. org/10.1111/ele.12795

Ostrovsky A.N. 2013. Evolution of Sexual Reproduction in Marine Invertebrates: Example of Gymnolaemate Bryozoans. Springer Verlag, Berlin and New York. https://doi.org/10.1007/978-94-0077146-8

Rust S. 2009. Plio-Pleistocene Bryozoan Faunas of the Wanganui Basin, New Zealand. PhD Thesis. University of Auckland, New Zealand.

Rust S. \& Gordon D.P. 2011. Plio-Pleistocene bryozoan faunas of the Wanganui Basin, New Zealand: stratigraphic distribution and diversity. New Zealand Journal of Geology and Geophysics 54 (2): 151165. https://doi.org/10.1080/00288306.2010.514928

Taylor P.D. \& Mawatari S.F. 2005. Preliminary overview of the cheilostome bryozoan Microporella. In: Moyano G., Hugo I., Cancino J.M. \& Wyse Jackson P.N. (eds) Bryozoan Studies 2004: 329-339. Balkema Publishers, Leiden, London, New York, Philadelphia, Singapore.

Waters A.W. 1887. On Tertiary cheilostomatous Bryozoa from New Zealand. Quarterly Journal of the Geological Society (London) 43: 40-72. https://doi.org/10.1144/GSL.JGS.1887.043.01-04.08

Manuscript submitted: 16 May 2016

Manuscript accepted: 9 January 2017

Manuscript published: 22 August 2017

Subject editor: Christian de Muizon

Desk editor: Danny Eibye-Jacobsen

Printed versions of all papers are also deposited in the libraries of the institutes that are members of the EJT consortium: Muséum national d'Histoire naturelle, Paris, France; Botanic Garden Meise, Belgium; Royal Museum for Central Africa, Tervuren, Belgium; Natural History Museum, London, United Kingdom; Royal Belgian Institute of Natural Sciences, Brussels, Belgium; Natural History Museum of Denmark, Copenhagen, Denmark; Naturalis Biodiversity Center, Leiden, the Netherlands; Museo Nacional de Ciencias Naturales-CSIC, Madrid, Spain; Real Jardín Botánico de Madrid CSIC, Spain. 